\title{
THE GREAT EXCEPTION
}




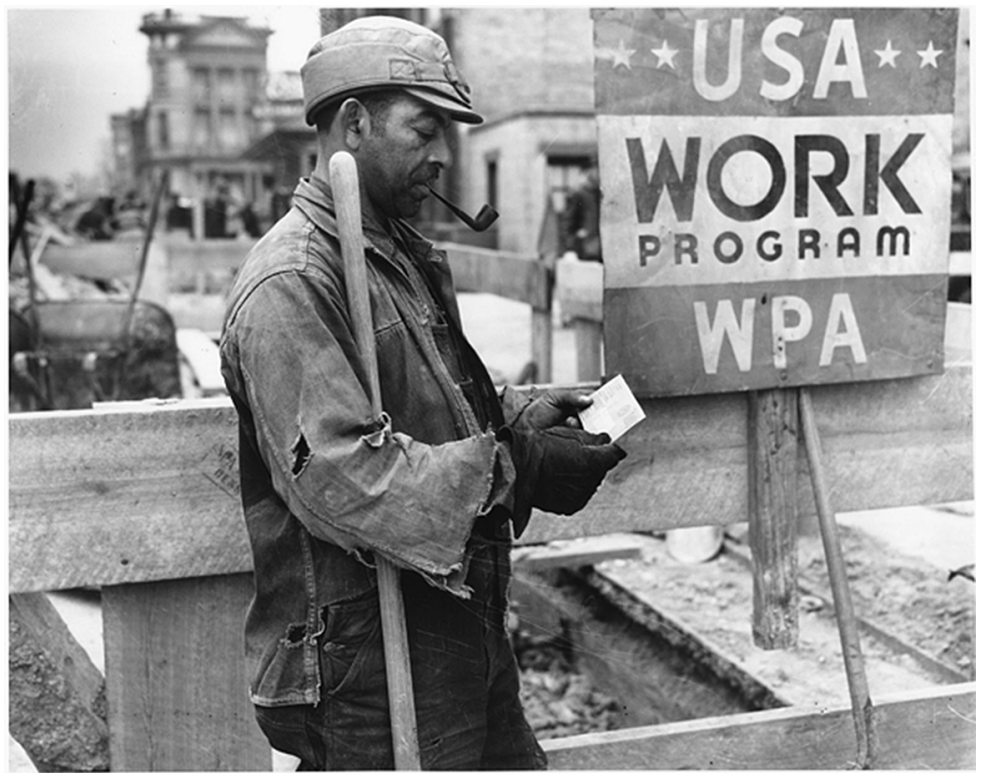

A WPA Employee Receives His Paycheck, 1939.

Courtesy National Archives. 

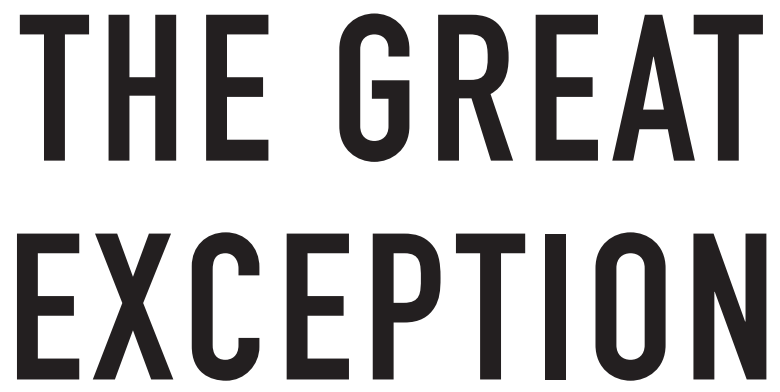

\section{THE NEW DEAL \& THE LIMITS OF AMERICAN POLITICS}

\section{JEFFERSON COWIE}

PRINCETON UNIVERSITY PRESS

Princeton and Oxford 
Copyright (C) 2016 by Jefferson Cowie

Requests for permission to reproduce material from this work should be sent to Permissions, Princeton University Press

Published by Princeton University Press, 41 William Street, Princeton, New Jersey 08540

In the United Kingdom: Princeton University Press, 6 Oxford Street, Woodstock, Oxfordshire OX20 1TW

press.princeton.edu

All Rights Reserved

Library of Congress Cataloging-in-Publication Data

Cowie, Jefferson.

The great exception : the New Deal and the limits of American politics / Jefferson Cowie.

pages $\mathrm{cm}$ - Politics and society in twentieth-century America Includes bibliographical references and index.

ISBN 978-0-691-14380-4 (hardcover : alk. paper) 1. United

States-Politics and government-1933-1945. 2. New

Deal, 1933-1939. 3. United States-Politics and government-1945-1989. 4. Liberalism-United States-

History-20th century. 5. Social conflict-United States-History20th century. 6. Political culture-United States-History20th century. 7. United States-Social conditions-20th century. E806.C68 2016

973.917-dc23

2015024474

British Library Cataloging-in-Publication Data is available

This book has been composed in DIN 1451 Std \& Sabon LT Std

Printed on acid-free paper. $\infty$

Printed in the United States of America

13579108642 


\section{FOR NICK,}

who taught me history,

voice, and friendship 
